\title{
Real Exchange Rate Misalignment and Economic Growth Nexus: Evidence from Southern African Countries
}

\author{
Knowledge Mutodi ${ }^{1}$, Eugine Tafadzwa Maziriri ${ }^{2}$ and Tinashe \\ Chuchu $^{3}$ \\ ${ }^{1}$ University of Zimbabwe, Department of Agricultural Business \\ Development \& Economics, Faculty of Agriculture Environment \\ and Food Systems, Zimbabwe. \\ 2 University of the Free State, Department of Business \\ Management, Faculty of Economic and Management Sciences, \\ South Africa. \\ ${ }^{3}$ University of the Witswatersrand, Marketing Division, School of \\ Business Sciences, Faculty of Commerce, Law and Management, \\ South Africa. \\ MaziririET@ufs.ac.za
}

\begin{abstract}
This paper investigates the link between real exchange rate misalignment and Southern African countries' economic growth. The study used panel data for 16 Southern African countries over 17 years. Generalized methods of moments (GMM) was applied to analyze the panel growth equation. The estimated results have suggested that the real exchange rate, real exchange rate misalignment, terms of trade, and foreign direct investment explains variation in income growth of southern African countries. The real exchange rate appreciation over the study period has adversely affected growth, whereas real exchange rate undervaluation suggests a positive impact on annual income growth. Unfavourable terms of trade were found to hurt growth, whereas foreign direct investment upsurge stimulates growth. Thus, policymakers in their respective African countries ought to diligently monitor real exchange rate misalignment in the foreign exchange market. An increase in real exchange rate overvaluation may adversely affect the trade and current account balances, which might ultimately hurt growth.
\end{abstract}

Keywords: real exchange rate misalignment, real exchange rate, terms of trade, foreign direct investment economic growth. 
JEL $\quad: 01, \mathrm{O} 2$

DOI : 10.24002/kinerja.v25i2.4401

Received : 03/05/2021 Reviewed: 06/27/2021 Final Version: 08/04/2021

\section{INTRODUCTION}

Money plays a central role in facilitating the exchange of goods and services within and between countries. Since Southern African countries trade with several countries, the real exchange rate determines the countries' internal and external equilibrium positions. A series of published papers have provided empirically grounded insights into how poorly managed exchange rates may be catastrophic for economic growth in developed and non-developed countries. The debate on the link between exchange rate movements and economic growth has been the key macroeconomic policy focus in discussions in Africa and beyond and is still ongoing.

Real exchange rates measure how much domestically produced goods and services can be exchanged for goods and services produced in another country (Ellis, 2001). Real exchange rates are an important concept when analyzing international transactions and their impact of exchange rates on different policy variables (Loretan, 2005). In addition, Darvas (2012) mentioned that the real exchange rate serves many purposes, such as assessing the currency's equilibrium value, cost competitiveness, the drivers of trade flows, and or incentives for reallocation of production between the tradable and the non-tradable goods sectors (Tsangarides, 2011). All these transactions reflect the transfer of money from one currency into another, respond to economic incentives, and optimise economic agents (Rose, Lockwood, \& Quah, 2000). Thus, the exchange rate is an important relative price in any economy. Effective management requires that monetary authorities have an idea of a crucial reference value called the equilibrium real exchange rate (ERER). This refers to the real exchange rate that would achieve either internal and external balances or the one that would achieve a target level of the growth and current account deficit. When the real exchange rate is not equal to the equilibrium exchange rate, it is misaligned. The equilibrium real exchange rate misalignment occurs when the actual or observed real exchange rate deviates from its equilibrium values (Cheung, Chinn, \& Fujii, 2007). This deviation can lead to undervaluation or overvaluation. Several studies have linked overvaluation to slow growth. Still, most studies tie it to macroeconomic instability while undervaluation is pointed out to facilitate economic growth just as sturdily as a decrease in overvaluation. Several studies have shown that in most countries, periods of fast growth are associated with undervaluation but with no evidence of non-linearity between growth and real exchange rate movements (Rodrik, 2008).

Hence, policymakers' proper reactions will be subject to understanding the types of shocks affecting the exchange rate and economic growth. This warrants the 
need to investigate the relationship between the exchange rate misalignment and economic growth but focusing on Southern African countries. The study aims to fully unpack and understand impact real exchange rate misalignment on economic growth to countries that are naturally linked due to geographic proximity.

\section{REAL EXCHANGE RATE CONCEPT}

Another way to think about the exchange rate is to think of the equilibrium level that attains external and internal equilibrium conditions (Cassino \& Oxley, 2013). The equilibrium exchange rate is the rate that would achieve either internal and external balances or the one that would achieve a target level of growth and current account deficit. The internal balance implies to output gap in production and no inflationary pressures in the economy. The external balance infers to a favourable position of balance of payments and maintenance of international reserves consistent with the stability of macroeconomic conditions (Omotosho, Olutope, Adeleke, Ajibola, \& Isaiaho, 2013). This equilibrium exchange rate is affected by many factors, such as fiscal policy, changes in technology, structural reforms, interest rates, inflation, the balance of payments, and many others. The theory assumes a market for foreign goods where demand and supply interact to determine market clearing conditions.

Even though we observe the bilateral nominal exchange rates, optimizing economic agents respond to real exchange rates. The real exchange rate definition in line with the purchasing power parity (PPP) theory compares two countries and the relative prices of baskets of goods produced (consumed). The purchasing power parity theory defines the real exchange rate as the long-run nominal exchange rate adjusted for price differentials between trading partners. The bilateral real exchange rate is calculated from the bilateral nominal exchange rate by considering price differentials between the trading partners (Opoku-afari, 2004). Mathematically, it can be written as follows:

$$
\mathbf{r}_{\text {ppp }}=\mathbf{e} \frac{\mathbf{P}_{\mathrm{f}}}{\mathbf{P}_{\mathrm{d}}{ }^{\prime}}
$$

where rppp is the real exchange rate, $\mathbf{e}$ is the bilateral nominal exchange rate, $\mathbf{p f}$ is the foreign price level and $\mathbf{P d}$ is the domestic price level. According to this definition, the decrease in the rppp can be interpreted as the real appreciation of the domestic currency. The increase of the real exchange rate represents the depreciation of the local currency, and the purchasing power of the local currency would have fallen in real terms (Ali, Johari, \& Alias, 2014).

Tradable goods sector (exports and imports) and non -tradable goods sectors respond to real exchange rates differently. The response depends on whether the real exchange rate is overvalued or undervalued, which is the degree of 
misalignment. The net response of exports, imports, and home goods depends on the real exchange rate's net function compared to the equilibrium real exchange rate (Cheung et al., 2007).

\section{REAL EXCHANGE RATE MISALIGNMENT}

The concept of real exchange rate misalignment assumes that countries facing internal disequilibrium accompanied external disequilibrium face misaligned real exchange rate. We can view this misalignment in both nominal and real views. These are the rates at which markets clear both in the domestic and international markets.

The equilibrium real exchange rate misalignment occurs when the actual or observed real exchange rate deviates from its equilibrium values. This real exchange rate misalignment depends on the implied level of equilibrium real exchange rate, which is also fluctuating and unobservable (Wakelin \& Gorg, 2002). This deviation can lead to undervaluation or overvaluation. If a country's real exchange rate is undervalued, it means the cost of a basket of goods in that country is lower compared to the cost of goods of its trading partners. Undervalued real exchange rates are normally assumed good since they promote the external trade sector and internal growth. If the real exchange rate is overvalued, the cost of basket goods in that country would be higher compared to the cost of goods of its trading partners (Auboin \& Ruta, 2013). Overvaluation leads to disincentive effects on the exportable goods sector, encourages imports and discourages exports and production of home goods.

Masunda (2011) defined the real exchange rate misalignment as below:

$$
\left(\mathrm{E}-\mathrm{E}_{\mathrm{t}}^{*}\right) \text {. }
$$

Where $\mathrm{E}$ is the observed value of the real exchange rate, $\mathbf{E}_{\mathrm{t}}^{*}$ is the value of the real exchange rate equilibrium. If $E-E_{t}^{*}>0$, the real exchange rate is overvalued, $\mathrm{E}-\mathrm{E}_{\mathrm{t}}^{*}<0$, the real exchange rate is undervalued. The real exchange rate is misaligned if it is not equal to the real exchange rate equilibrium (Masunda, 2011).

Masunda (2011) contents that an overvalued real exchange rate can result in the loss of external competitiveness of an exporting country, and sell of goods in foreign markets becomes difficult. Overvalued currency can also affect the industrial sector because of backward and forward linkages with other sectors, like agriculture. Firms find it cheaper to forgo domestic inputs, in favour of inputs produced by foreign firms. This could fuel trade balance deficits and affect the 
domestic market of import-competing firms. As a result, both the domestic and international markets are affected (Omotosho et al., 2015).

A misalignment of the real exchange rates, also causes economic agents to have expectations of price uncertainties affecting investment (Obayelu \& Salau, 2010). A fall in investment results in a drop in future production by firms and future employment. The loss of jobs as a result of the overvalued real exchange rate has secondary effects on the entire economy. This fuels a fall in aggregate demand corresponded to a further fall in production and further unemployment through the multiplier effects, creating problems for monetary authorities (Masunda, 2012). Rodrik (2008) supported the same view that overvalued currencies can cause foreign currency shortages, rent-seeking and corruption, large persistent current account deficits, the balance of payments problems, and stop-and-go macroeconomic cycles, all with a negative impact on economic growth.

\subsection{Influence of real exchange rate misalignment on growth}

Several research types have been carried out in the past decade to find the impact of real exchange rate misalignment on growth both in developing and developed countries. Different conclusions have been reached regarding the effect of real exchange rate misalignment on growth. Evidence has shown that undervaluation facilitates economic growth, particularly in developing countries while overvaluation hurts growth. Nevertheless, there is little evidence on nonlinearity between undervaluation and growth. The effect of real exchange rate misalignment on growth and the convergence of developing countries' incomes to those of developed economies remains deliberated.

Mohieldin and Elsherif (2016) investigated real exchange rate misalignments and economic growth on Arab Countries. The paper used panel data from 2000 to 2016 . Real exchange rate misalignment was estimated using a single equation model. The generalized Method of Moments (GMM) technique was applied to analyze the impact of real exchange rate misalignment on growth. Estimation results have revealed that the real exchange rate misalignment harmed economic growth. This implied that the real exchange rate misalignment has an unfavorable impact on growth in Arab countries.

Developing country experiences have shown that sizeable and prolonged overvaluations are linked to sluggish growth. However, there also arguments on whether undervaluation promotes growth, or it hampers in developing countries. Countries cannot maintain an undervaluation indeterminately, thus it can only be used as a growth tool only in the short run. 
Omotosho et al. (2015) assessed real exchange rate misalignment and economic growth in Nigeria. The paper used quarterly data spanning from 2000 2014. Real exchange rate misalignment was computed from the equilibrium real exchange rate obtained using the behavioral equilibrium exchange rate approach of Edwards (1989). The naira has found to be overvalued by 0.17 percent during the period of the study. Real exchange rate misalignment was found to negatively affect economic growth. It was recommended that the government use marketbased exchange rate misalignment to ensure that the naira real exchange rate follows its path of sustainable equilibrium.

Further, Thandinkosi (2011) cited Toulaboe (2006) who also carried out on the impact of exchange rate misalignment on developing countries' economic growth. The paper used recent panel data from 33 developing countries. The link between real exchange rate misalignment and economic growth was assessed. The estimation results indicated that real exchange rate misalignment was negatively related to economic growth. It has been concluded that incorrect exchange rate policies could have contributed to sluggish economic performance many developing countries face.

Omotosho et al., (2013) Cited collins (1997) who used labor productivity, annual money growth, and terms of trade, annual long-term capital flows, and annual resource balance. Misalignments were found to be most noticeable in SubSaharan Africa, South \& Central Asia, and Europe. A 10 percent real exchange rate overvaluation was connected to a reduction in real per capita output by 0.6 percent. Moderate undervaluation was found to be linked with fast economic growth.

Thandinkosi, (2011) investigated the relationship between real gross domestic product growth and real exchange rate misalignment for Zimbabwe. The study controlled structural and policy variables. Estimation results have indicated that the real exchange rate misalignment negatively affects economic growth. The study concluded that prolonged real exchange rate overvaluation was an important factor behind the post-2000 economic growth collapse.

Razin and Collins (1997) constructed an indicator of real exchange rate misalignment based on the extension of the IS-LM model of an open economy. The sample comprised of developed and non-developed countries. A regression model was used to explore the relationship between the real exchange rate misalignment and economic growth experiences. The estimation results indicated non-linearities in the relationship. However high overvaluations were linked to slow growth while moderate to high undervaluation seemed to be linked to fast economic growth. 
Ulaşan (2018) examined the association between real exchange rate misalignment and economic growth. The study used panel data over the sample period between 1990 and 2014 for a large number of countries. The result indicated that the real exchange rate misalignment was positively associated with low and middle-income countries' economic growth. And there was an insignificant relationship between the two richer countries. This implied that in the long run, the more overvalued the currency, the lower the long-run growth rate per capita income in developing countries.

WB (2016) also investigated the real exchange rate misalignment and its relationship to output growth in South Africa. The paper used a simple theorybased real exchange rate misalignment index for countries worldwide from 19502014. Estimation results have shown that South Africa's RER has been undervalued for the past 10 years. And terms of trade fluctuations were found to explain a large part of undervaluation.

Gala and Lucinda (2006) examined the relationship between real exchange rate and economic growth based on panel data for 58 developing countries from 1960 to 1999 using new econometric measures. The Generalized Method of Moments (GMM) estimation technique was chosen because of its ability to deal with measurement errors and endogeneity problems. The focus of the study was to find the impacts of overvaluations on growth. After correcting for Balassa Samuelson effect, the estimates using the real exchange rate corrections for productivity differentials (proxied by per capita income differentials) indicate that both the absolute value and significance of the coefficient associated with overvaluations are relevant. This shows that productivity differentials could have a significant role in the impact of real exchange levels on per capita real income growth rates. The estimated results have shown a highly significant negative impact of 0.0122 . This implies that a 10 percent real exchange rate devaluation assuming everything else remaining constant, could trigger a 0.122 percent increase of real per capita income average growth rates

Looking at India as the other recent growth superstar after China, the India GDP growth has gradually increased from slightly above 1 percent a year in the 1950 s to 4 percent by the early 2000s, whereas its real exchange rate has moved from small overvaluation to an undervaluation of about 60 percent. However, the case of East Asian giants is that South Korea and Taiwan the slowdown in growth in the recent years were in each case followed by a rise in overvaluations or reduced overvaluation. This has however, shown both that growth and undervaluation exhibit an inverse- $U$ shape over time. African experiences particularly those of Uganda and Tanzania have shown that a growth slowdown is accompanied by increasing overvaluation and a pick growth is associated with an increase in undervaluation. The case of Latin America is that Mexico's experience 
has shown no relationship between growth and undervaluation. This may be because periods of capital inflows in Mexico are linked with consumption-led growth booms and currency appreciation; when the capital flows reverse, the economy tanks and the currency depreciates (Rodrik, 2008).

It is important however to note that, most studies that have carried out the impact of real exchange rate misalignment on growth have found that undervaluation of the real exchange rate tends to facilitate economic growth, especially in developing countries while in developed countries the evidence is not clear.

\section{METHODOLOGY}

A country experiences bilateral nominal exchange rates (BNER) with all its trading partners, "importers and exporters, remittances by country's citizens working abroad, and foreigners' remittances involving all international transactions (RBZ, 2015). The BNER is the price of foreign currency (direct quote) expressed in terms of domestic currency or vice versa (indirect quote). The BNERs without being adjusted for inflation might be insufficient to measure the impact of real exchange rate misalignment on economic growth. Thus, there is a need to compute the real exchange rate. The Real Exchange Rate (RER) measures the relative purchasing power of the two currencies. For instance, the RER of the Pula versus the U.S. dollar is the purchasing power of the Pula versus the dollar. It is calculated as the dollar price of the Pula (the nominal exchange rate) times the dollar price of one unit of the consumption basket in the U.S. divided by the Pula price of one unit of the consumption basket in Botswana. A country's PPP gives the number of local currency units that are required to buy a bundle of products worth one dollar for example in the USA. If the nominal exchange rate (measured in local currency units per US dollar) is divided by the PPP; then it gives "the price level" of that country relative to the USA. Thus "Purchasing power parities (PPPs) are the rates of currency conversion that equalize the purchasing power of different currencies by eliminating the differences in price levels between countries" (Nguyen, 2015). In other words, it is the rate of currency conversion between for example the pula the U.S dollars so that $R E R c, U S=1$ (i.e. the purchasing power of the Pula and the U.S. dollar are equalized). The real exchange rate is calculated as follows:

$$
\begin{aligned}
& R E R_{c}, \text { us }=N E R_{c} \text {, us } \frac{\text { price USD }}{\text { Price PULA }} \\
& P P P_{c}, \text { us } \frac{\text { price USD }}{\text { Price PULA }}=1
\end{aligned}
$$


$R E R_{c}, u s=\frac{N E R}{P P P}$

Usually, developing countries' real exchange rates are greater than one. This implies that the prices of goods and services in developing countries are cheaper than those of the US and other developed countries. A possible explanation about this could the Balassa-Samuelson effect. The BalassaSamuelson effect captures the economy's productivity effect on its non-tradable goods' prices. Normally, it has been observed that the price of services is higher in developed countries when compared to that of developing nations, for in developed countries wages are higher due to the tradable sector of the developed countries that have higher productivity than in developing nations. Assuming the law of one price on the tradable goods sector, this suggests that tradable sector wages paid to workers are higher to match their high productivity. Thus cheaper prices could be primarily explained by low productivity in developing countries (Rodrik, 2008).

Whereas nominal exchange rates can be observed varying daily and irregularly, real exchange rates are also varying daily and irregularly at various speeds and cycles but are unobservable. Statistical methods have been developed to measure these fluctuations and misalignment. Some of the statistical methods which have been developed to measure misalignment are the pooled OLS regression for panel data. Nevertheless, before computing the real exchange rate misalignment, the real exchange rate variable is first adjusted for the BalassaSamuelson effect as discussed earlier. The "Balassa- Samuelson (BS) effect" which predicts that as countries get richer, the higher the price of goods of its nontradable sector (Couharde, Delatte, Grekou, Mignon, \& Morvillier, 2019).

The BS effect is adjusted by running the following regression:

$$
\operatorname{lnRER}_{i t}=\beta_{0}+\beta_{1} \operatorname{lnGDP} \text { per } \text { Capita }_{i t}+\text { tteit }
$$

Where RER is the computed real exchange rate based on equation (3), GDP per capita in the country $i$ at time $t$, $\tau$ t are year dummies the coefficient $\beta_{1}$ captures the Balassa-Samuelson effect with an expected negative sign. The rationale behind is that per Balassa-Samuelson effect, a country RER, at any given time, is larger if its output per capita (a proxy for productivity) is lesser. And sit will be our real exchange rate misalignment variable of country $i$ where sit is the residual of the regression. A positive sit suggests an undervalued RER. That is, the RER is larger (more depreciated) while negative suggest an overvalued RER, that is the RER is smaller (more appreciated). Thus, residuals attained from this regression are then taken as our real exchange rate misalignment measure, which takes into account and control for the Balassa-Samuelson effect. 
The computed real exchange rate misalignment is then taken together with other variables into the growth model as shown below;

$\ln ($ GDP/Capitait $)=\beta 0+\beta 1$ InPop it $+\beta 2 \operatorname{InRER}$ it $+\beta 3$ InTOTit $+\beta 4$ RERMit $+\beta 5$ $\operatorname{lnFDlit}+\varepsilon t$

Where GDP per capita of country $i$ at time $t$, Pop it is the population of the country I at time $t$, RERt is the real exchange rate of the country I at time $t$, TOTt is the terms of trade of country $t$ at time $t$, RERMt is the real exchange rate misalignment of the country $\mathrm{I}$ at time $\mathrm{t}$, FDI $\mathrm{t}$ is the foreign direct investment of country $\mathrm{i}$ at time $\mathrm{t}$ and $\mathrm{ct}$ is the error term. The growth model is estimated using the generalized methods of moments (GMM) estimation technique, which is flexible enough to deal with the measurement errors and endogeneity problems.

\section{DATA AND DATA SOURCES}

The paper uses published secondary annual time series data with a crosssectional dimension (Panel data) for 16 Southern African Development Community (SADC) countries from 2000 to 2017. Apart from real exchange rate misalignment, other variables such as gross domestic product GDP, nominal exchange rate, terms of trade, foreign direct investment, the population in millions were sourced from International Monetary Fund's International Financial Statistics, Penn World Table 9.1 and World Development Indicators 2019. The estimation period choice from 2000 to 2017 was based on data availability for some key variables. However, most developing countries face data collection, compilation, and processing challenges, particularly during inflationary periods when prices change dramatically. These changes are both unclear and problematic, making both static analysis and dynamic analysis and interpretation very strenuous.

\subsection{Estimation procedure and results}

As aforementioned, the real exchange rate misalignment is computed by regressing the real exchange rate variable on annual GDP per capita, which accounts for the Balassa-Samuelson effect as shown in equation 5 . However, it is important to note that the measure of real exchange rate misalignment is the predicted residuals obtained from the auxiliary model in equation 4 , not the actual error terms. The estimated regression results in Table 1 below show a $\beta\left(\beta^{\wedge}\right)$ of -0.015427 and highly significant at 1 percent level, suggesting a fairly strong Balassa-Samuelson effect. The coefficient indicates that when income increase by 10 percent, the real exchange rate falls by around 1.5 percent. 
Table 1. Balassa-Samuelson effect

Dependent Variable: LN Gross Domestic Product per Capita

Method: Panel Least Squares

\begin{tabular}{lllll}
\hline Variable & Coefficient & Std. Error & t-Statistic & Prob. \\
\hline LN Real Exchange Rate & -0.015427 & 0.005457 & -2.826918 & 0.0050 \\
C & 7.253499 & 0.075470 & 96.11061 & 0.0000 \\
\hline
\end{tabular}

The baseline specification for estimating the link between real exchange rate and growth takes the form in equation 6 . The real exchange rate misalignment adjusted for the Balassa- Samuelson effect is taken together with other variables, shown in equation 6. Following the recent literature as regards to panel data studies, the dynamic approach or the generalized method of moments (GMM) is applied as the estimation method as it is the most appropriate for evaluating the real exchange rate misalignment and economic growth nexus for SADC countries. It accounts for time persistence in economic growth. The difference GMM is applied, and lagged values of the variables are used as instrumental variables. These models use lagged values of regressors (in levels and in differences) as instruments for right-hand-side variables and allow lagged endogenous (left-handside) variables as regressors in short panels (Rodrick 2008). The overall validity of the instruments is tested using the Sargan test. The generalized method of moments (GMM) is principally suitable in this respect as this estimator alleviates the endogeneity bias stemming from the time-invariant omitted variable and simultaneity and measurement errors (Gala \& Lucinda, 2006).

Table 2. Panel Generalized Method of Moments Results

Dependent Variable: LN GDP Per Capita

\begin{tabular}{lllll}
\hline \hline Variable & Coefficient & Std. Error & t-Statistic & Prob. \\
\hline \hline LNGDPP (-1) & -0.034170 & 0.033537 & -1.018878 & 0.3093 \\
LN Terms of trade & -0.186024 & 0.072010 & -2.583318 & 0.0104 \\
LN Foreign direct investment & 0.023094 & 0.007695 & 3.001194 & 0.0030 \\
Real exchange rate misalignment & 0.718200 & 0.050696 & 19.88714 & 0.0000 \\
LN Real exchange rate & -0.018757 & 0.001220 & -15.37891 & 0.0000 \\
LN Population & 0.116610 & 0.104846 & 1.112200 & 0.2672 \\
\hline \hline
\end{tabular}

Authors' estimations 
Table 2 suggests that real exchange rate misalignment, real exchange rate, terms of trade, foreign direct investment explains most of the variations in Gross domestic per capita of all SADC countries. The variable of interest are real exchange rate misalignment and the real exchange rate. The two variables were found to be highly significant at 1 percent level. A 10 percent increase in exchange rate misalignment (undervaluation) has a 71.8 percent positive impact on GDP per capita's annual growth. The real exchange rate has been found to negatively affect GDP per capita. A 10 percent appreciation of the real exchange rate has a 1.88 percent negative effect on GDP per capita growth. However, terms of trade were found to be significant at 1 percent level with a coefficient of -186024 . This implies that a 10 percent increase in unfavorable terms of trade has an 18.6 percent negative effect on annual GDP growth per capita. Foreign direct investment has a positive coefficient of 0.023094 . This suggests that a 10 percent increase in foreign direct investment has a positive impact of 2.3 percent on annual GDP per capita growth.

\section{DISCUSSION AND POLICY IMPLICATIONS}

\subsection{Real exchange rate and growth}

The real exchange rate is one of the most key prices in an open economy. It signals how the economy's structure should adjust to the internal and external sectors to maintain equilibrium. Evidence has shown that real exchange rate appreciation negatively affects GDP per capita of Southern Africa countries. A 10 percent appreciation of the real exchange rate has a 1.88 percent negative effect on GDP per capita growth. This suggests that a general real appreciation of the exchange rate for countries in Southern Africa may hurt growth. This is because the real appreciation of domestic currencies increases export prices leading to loss of external competitiveness on the international market, affecting economic growth. So, in particular, African countries should constantly avoid real exchange rates overvaluations to recuperate competitiveness in the export sector and attract higher levels of investment, which may result in output and employment growth.

\subsection{Real exchange rate misalignment and growth}

The cross-country evidence between real exchange rate misalignment and income has shown that a 10 percent in real exchange rate undervaluation has a 71.8 percent positive impact on GDP per capita's annual growth. This suggests that real exchange rate undervaluation exerts a significant impact on economic growth in countries in Southern Africa. Thus, in general, African countries could choose to follow a policy of currency undervaluation in real terms to stimulate consistent demand for exports as part of a long-run growth strategy. And further, undervaluation could increase the rate of return to capital used in the production of tradable goods by an amount adequate to overcome the widespread institutional 
challenges that excessively affect African economies. However, African countries ought to be able to undertake monetary policy measures that make it possible to maintain an undervalued currency over time.

\subsection{Terms of Trade, Foreign Direct Investment, and Growth}

The results also indicate that unfavorable terms of trade negatively affect economies in southern African countries. A 10 percent increase in trade unfavorable terms has an 18.6 percent negative effect on annual GDP growth per capita. Thus, countries in Southern Africa ought to focus on improving terms of trade to boost economic growth. Since the higher the terms of trade, the greater a country's gain from price developments in the foreign sector.

Further, cross country evidence has shown that a 10 percent increase in foreign direct investment has a positive impact of 2.3 percent on Southern African countries' annual GDP per capita growth. This suggests that an increase in foreign direct investment inflows could substantially drive technology transfer and improvements, job and skills formation, and export growth. Thus, African countries should focus on doing business and investment climate reforms intended at growing FDI inflows that can have the beneficial effect of increasing output and employment while helping finance the current account deficits.

\section{CONCLUSIONS}

The growth regression model results suggest that the real exchange rate, real exchange rate misalignment, terms of trade, and foreign direct investment explain most of the variations in the income growth of southern African countries. The results support several case studies on developing countries on the impact of real exchange rate misalignment on growth. The real exchange rate has been found to affect growth negatively. That is 10 percent real exchange rate appreciation reduces annual growth by 1.88 percent. An obstinately appreciating real exchange rate may lead to lower GDP growth since foreign capital is likely attracted to countries with cheap exchange rates. African countries should avoid persistent real exchange rate appreciation to attract foreign capital. Concerning real exchange rate misalignment, a 10 percent increase in real exchange rate undervaluation has been found to boost annual economic growth by 71.8 percent. The results are in line with other studies conducted on a similar subject matter in the past. Southern African countries may choose to follow currency undervaluation as a growth strategy to improve foreign capital inflows and export growth, resulting in highincome growth. Undervaluation could influence domestic and foreign investments, thus making the capital accumulation process widely considered a growth engine. The real exchange rate is a policy determined variable therefore, this may require 
intervention in the foreign exchange market to maintain undervaluation over time since persistent overvaluation may harm growth. This research as well find terms of trade and foreign direct investment as essential variables that affect Southern African countries' income growth. A 10 percent upsurge in unfavorable trade terms has an 18.6 percent adverse outcome on annual GDP growth per capita. This authorizes the need for Southern African countries to focus on policies that improve terms of trade as it has a substantial impact on growth. Foreign direct investment was also found as a significant factor that affects growth in southern African countries. A 10 percent upsurge in foreign direct investment may boost annual economic growth by 2.3 percent. This implies that policies focused on attracting foreign capital should be put in place to spur growth in the southern and Africa as a whole.

\section{REFERENCES}

Ali, D. A., Johari, F., and Alias, M. H. (2014). The Effect of Exchange Rate Movements on Trade Balance: A Chronological Theoretical Review. Economics Research International, 2014, 1-7. https://doi.org/10.1155/2014/893170

Auboin, M., and Ruta, M. (2013). The Relationship Between Exchange Rates and International Trade: A Review of Economic Literature. In World Trade Review (No. G32). https://doi.org/10.1017/S1474745613000025

Cassino, E., and Oxley, D. (2013). Exchange rate valuation and its impact on the real economy. New Zealand Treasury, (March 2013), 1-39.

Cheung, Y., Chinn, M. D., and Fujii, E. (2007). The overvaluation of Renminbi undervaluation. 26. https://doi.org/10.1016/j.jimonfin.2007.04.005

Couharde, C., Delatte, A., Grekou, C., Mignon, V., and Morvillier, F. (2019). Working Paper.

Darvas, Z. (2012). Real Effective Exchange Rates for 178 Countries: A NewDatabase. In Bruegel Working Paper (Vol. 06).

Ellis, L. (2001). Measuring the Real Exchange Rate: Pitfalls and Practicalities (No. 2001-04). Retrieved from www.rba.gov.au

Gala, P., and Lucinda, C. R. (2006). Exchange Rate Misalignment and Growth: Old and New Econometric Evidence. Revista EconomiA, 7(December), 165-187. 
Loretan, M. (2005). Indexes of the Foreign Exchange Value of the Dollar. In Federal Reserve Bulletin (Vol. 91). Retrieved from http://0search.ebscohost.com.library.ucc.ie/login.aspx?direct=true\&db=ofm\&AN=5105073 44\&site=ehost-live [Accessed 7 February 2021].

Masunda, S. (2011). Real Exchange Rate Misalignment and Sectoral Output In Zimbabwe. Interantion Journal for Economic Resources., 2(August), 59-74. Retrieved from www.ijeronline.com [Accessed 7 February 2021].

Masunda, S. (2012). Real Exchange Rate Misalignment and Currency Crisis in Zimbabwe. Journal of Emerging Trends in Economics and Management Sciences, 3(6), 923-930. Retrieved from jetems.scholarlinkresearch.org

Mohieldin, M., and Elsherif, M. (2016). Real Exchange Rate Misalignments and Economic Growth: Evidence from Arab Countries. Retrieved from http://data.worldbank.org/region/arab-world [Accessed 7 February 2021].

Nguyen, H. (2015). Republic of South Africa Systematic Country Diagnostic An Incomplete Transition: Overcoming the Legacy of Exclusion in South Africa. Pretoria.

Obayelu, A. E., and Salau, A. S. (2010). Agricultural Response to Prices and Exchange Rate in Nigeria: Application of Co-integration and Vector Error Correction Model (VECM). Journal of Agricultural Science, 1(2), 73-81.

Omotosho, B.., Olutope, A., Adeleke, A., Ajibola, A., and IsaiahO, A. (2015). Real exchange rate misalignment and economic growth in Nigeria. Journal of Economic Studies, 40(2), 298-313.

Opoku-afari, M. (2004). Measuring the Real Effective Exchange Rate (REER) in Ghana by (No. 04/11). Retrieved from https://www.nottingham.ac.uk [Accessed 7 February 2021].

Razin, O., and Collins, S. M. (1997). misalignment real.pdf (No. 6174). Retrieved from htt://www.nber.org/papers/w [Accessed 7 February 2021].

RBZ. (2015). Assessing The Impact Of The Real Effective Exchange Rate On Competitiveness In Zimbabwe. In RBZ Working Paper Series. Retrieved from www.rbz.co.zw/monetary-policy.html [Accessed 7 February 2021].

Rodrik, D. (2008). The Real Exchange Rate and Economic Growth. 432 Brookings Papers on Economic Activity, (1997), 365-439.

Rose, A. K., Lockwood, B., and Quah, D. (2000). Center for Economic Studies Maison des Sciences de l'Homme Centre for Economic Policy Research One 
Money, One Market: The Effect of Common Currencies on Trade. Source: Economic Policy, 15(30), 7-45.

Thandinkosi, N. (2011). Munich Personal RePEc Archive Implications of real exchange rate misalignment in developing countries: theory, empirical evidence and application to growth performance in Zimbabwe (No. 32710). Retrieved from https://mpra.ub.uni-muenchen.de/32710/ [Accessed 7 February 2021].

Tsangarides, C. G. (2011). Working Paper No. 2011 / 14 Exchange Rate Regimes and Trade Is Africa Different? Mahvash Saeed Qureshi and.

Ulaşan, B. (2018). Real Exchange Rate Misalignment and Economic Growth: An Update (No. 18/19).

Wakelin, K., and Gorg, H. (2002). The Impact of Exchange Rate Volatility on US Direct Investment. The Manchester School, 70(3), 380-397.

World Bank. (2016). Zimbabwe Economic Update (No. 1). Retrieved from www.worldbank.org. [Accessed 7 February 2021]. 


\section{APPENDIX A: Table 1}

Dependent Variable: LNGDP_P_C

Method: Panel Least Squares

Date: 06/27/20 Time: $16: 14$

Sample: 20002018

Periods included: 19

Cross-sections included: 16

Total panel (unbalanced) observations: 291

\begin{tabular}{lrlll}
\hline \hline \multicolumn{1}{c}{ Variable } & Coefficient & Std. Error & t-Statistic & Prob. \\
\hline \hline \multicolumn{1}{c}{ RER } & -0.015427 & 0.005457 & -2.826918 & 0.0050 \\
\multicolumn{1}{c}{ C } & 7.253499 & 0.075470 & 96.11061 & 0.0000 \\
\hline \hline R-squared & 0.026908 & Mean dependent var & 7.327378 \\
Adjusted R- & & & \\
squared & 0.023541 & S.D. dependent var & 1.222248 \\
S.E. of regression & 1.207776 & Akaike info criterion & 3.222287 \\
Sum squared resid & 421.5707 & Schwarz criterion & 3.247533 \\
Log likelihood & -466.8427 & Hannan-Quinn criter. & 3.232401 \\
F-statistic & 7.991467 & Durbin-Watson stat & 0.055830 \\
Prob(F-statistic) & 0.005028 & & & \\
\hline \hline
\end{tabular}

